\title{
Discussion on the Self in "Milindapañha" on Chariot: New Translation and Comments
}

\author{
Lev I. Titlin \\ Institute of Philosophy, Russian Academy of Sciences, \\ 12/1, Goncharnaya Str., Moscow, 109240, Russian Federation, \\ titlus@gmail.com
}

\begin{abstract}
The article offers a new English translation of passages from "Milindapañha" about the self and author's comments thereto. The translation is preceded by a brief summary of the ancient treatise. The author polemicizes with contemporary philosophers such as M. Siderits and comes to the conclusion that Siderits is actually not a reductionist as he claims himself to be, but rather an emergentist, or a follower of systems theory; this is confirmed by his turn to the passages from "Milindapañha" being translated, that the author suggests examining from the perspective of systems theory and asserts that early Buddhism as it is given to us, in particular, in the text under examination, rather leans not to reductionism and a mere negation of the "self" or "subject", but to a soft version of the theory of emergentism. The author expresses his disagreement with the "semiotic interpretation" of the issue by A. Paribok and, as confirmation of his ontological-epistemological interpretation, refers to such texts as "Kathāvatthu", "Vajirā Sutta" and "Pudgalaviniścaya" of Vasubandhu. The conclusion is that if early Buddhism (that is, as a minimum in the 1st century AD, in "Milindapañha") speaking of the self, rather adhered to the systems theory and emergentism (non-reductionism), then by the 4th century (Vasubandhu "Abhidharmakośa") there we see a significant shift towards annihilationism (reductionism) and the subject (the self, I) starts to be directly negated in scientific treatises.
\end{abstract}

Keywords: Milindapañha, emergentism, self, subject, ātman, anātman, systems theory, non-reductionism

\section{Article history:}

The article was submitted on 05.01.2021

The article was accepted on 10.02.2021

(C) Titlin L.I., 2021

This work is licensed under a Creative Commons Attribution 4.0 International License https://creativecommons.org/licenses/by/4.0/ 
For citation: Titlin L.I. Discussion on the Self in "Milindapañha" on Chariot: New Translation and Comments. RUDN Journal of Philosophy. 2021;25(2):260-275. DOI: 10.22363/23132302-2021-25-2-260-275

\section{Introduction}

A good example of emergentism - interpreted by M. Siderits [1] as Buddhist reductionism) is an excerpt from the dialogue between King Milinda ${ }^{1}$ and the monk Năgasena ${ }^{2}$ about the self, which is part of the text close to the Abhidhamma tradition entitled "Milindapañha" (or "Questions of King Milinda"). The text was published by V. Trenckner in 1880 in [2] and translated into English by T.W. Rhys Davids [3] in the series "Sacred Books of the East". Furthermore, there is an English translation by I. B. Horner [4] and Bhikkhu Pesala [5] and into Russian by A.V. Paribok [6]. There are also German [7] and French translations [8;9]. Yet the classical translation by Rhys Davids is currently largely obsolete. Paribok's translation into Russian is not convenient for practical use as it would need to be further translated into English, and this double translation, which is not very good from the point of view of the philological approach to the text. We have therefore decided to make our own, new translation of the passage from "Milindapañha", in which the dialogue about the self is being held.

"Milindapañha" is a dialogue between the Buddhist monk Nāgasena and "King Milinda" identified by the researchers as the Indo-Greek king Menander I

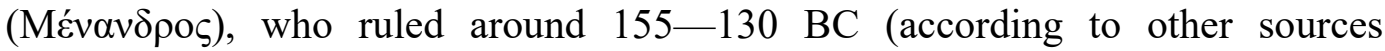
165-130 BC) in Sāgala, or Siyālkoț in the Indian region of Punjab [10]. "Milindapañha" has been preserved in several editions of early Buddhist schools, namely Sarvāstivāda, Theravāda and others, in particular, in several Chinese versions, in Pali, Sanskrit and Prakrit. It can be assumed that the original version of the text was created during the reign of Manander I.

"Milindapañha" is divided into 7 books. The first book, "The Outer Narrative", tells first about the city where the action takes place, then about the previous reincarnations of Milinda and Nāgasena. It is then told that Milinda who, in one of his incarnations, was a Buddhist novice, in another one - a god, and now a king "loving to engage in arguments and willing to engage in debates with reasoners, objectors and the like", in a word, a person, as the saying goes, inclined to philosophize, walks around visiting various philosophers of that time, as well as a Buddhist sangha where he asks tricky questions about the arrangement of the

\footnotetext{
${ }^{1}$ Milinda is being identified with the Greek-Bactrian king Menander, who reigned about $150 \mathrm{BC}$. His rule was the result of the conquests of Alexander the Great.

${ }^{2}$ It is not known whether Nāgasena can be identified with any historical figure. Yet there is no doubt that such dialogues might indeed have occurred between the Greco-Bactrian kings and Buddhist monks. The fact that a similar dialogue is found in "Pudgalivinisćaya" - the 9th book of "Abhidharmakośa-bhāṣya" (4th century) — indicates that the dialogue might actually have taken place and that Nāgasena might well have been a real person. In this passage, Milinda, referred to in the text as Kalinga, is talking with the "wandering ascetic" Nāgasena. The dialogue is a continuation of the discussion in "Milindapañha". For the dialogue itself, translated into English, see below.
} 
universe. Ultimately, the gods ask a certain Mahasena to descend from the divine abode and incarnate in a person in order to adequately answer Milinda's questions and protect the Buddhist teaching. So Mahasena reincarnates in Nāgasena.

In the first chapter of Book 2 ("Questions About Characteristics"), a classic comparison of the self with a chariot is given, (for more on this see below). In the second chapter traditional Buddhist examples are used to explain the continuity of personality, which is compared to the sequence of fire moving through the burning, or milk-curd-butter-ghee. Milinda asks the question of what is being reborn, and Nāgasena replies that that is the name-form (nāma-rūpa), i.e. the psychophysical complex (by nāma the subtle, or mental is meant, and by the rūpa, the gross, or body) under the influence of actions in previous birth. Another interesting question raised by Milinda is that of time. Nāgasena actually asserts the relativity of the existence of time, saying that it exists only for those beings who continue to be reborn.

The third chapter deals with issues of causality (pratītya-samutpāda), and also asserts that the soul (vedagū, lit. one who attains knowledge) does not exist as an internal knower who can act in the same way through all the senses (since each sensory ability is independent). Along with this, consciousness is considered as awareness in relation to objects given to the senses and the mind.

Book 3, "The Removal of Difficulties", argues that differences between people are due to differences in the seeds of karma and that liberation is cessation. Subjectless rebirth is illustrated with the following examples: lighting one lamp from another, recalling a previously forgotten verse. It is also said that the Buddha continues to exist - in his teachings - despite the fact that he went into nirvana.

In the fourth book, "Resolving Dilemmas, " Milinda asks Nāgasena antinomic questions, for instance: if the Buddha has attained final liberation, so how can he be honored? After all, if he can be honored, then it turns out that he has not attained liberation. The second chapter of the fourth book introduces the category of questions that cannot and must be answered (avyākata), such as whether the world is eternal or not. Basically, the book deals with specific passages from the Buddhist Scriptures that Milinda finds to be contradictory. In chapter four, an interesting passage is devoted to a discussion on the question of karma. For example, there was a certain Devadatta who did a lot of evil and at the same time he had several favorable reincarnations which were even better than those of the Buddha in past lives. Nāgasena comments that one must not take into account only a few lives, separately from a longer period of time, because Devadatta ultimately got moral retribution having stayed many lives in the purgatory, whereas the Buddha was reborn many times as a god in the divine worlds. Chapter Six discusses the question of why there cannot be more than one buddha in the world at a time. The following reasons are given: the world would not be able to support such a quantity of good, the followers of these buddhas would quarrel, the scriptures cannot refer to different buddhas at a time, two forces too strong cannot exist in the world at the same time as one cannot weaken the other. 
In chapter seven, Milinda also enumerates three things that cannot be found in this world: a thing that is not subject to destruction, a constant quality and any acquisition of being (satta). Nāgasena asserts that there are only two things in the world that are causeless: empty space (ākāsa) and nibbāna, which surprises Milinda: shouldn't liberation have its own causes? To this, Nāgasena replies that nirvana itself is non-composite and therefore causeless, but the realization of nirvana has its causes.

An interesting observation is made in the eighth chapter: virtue is stronger than vice because it lasts longer. The book also explores the nature of sleep. Nāgasena says that a dream is a sign in the mind. There are six kinds of people who see dreams: those dominated by wind, or by bile, or by phlegm, those who dream dreams by the influence of gods, by their own influence, those who see prophetic dreams. Yet only prophetic dreams - which are similar to reflections in a lookingglass - have a true nature. All dreams require interpretation, and their meaning may not be obvious. Dreams are not seen in the state of deep sleep, because in it, awareness returns to the life continuum and is, as it were, covered by a dream, though actually present. There are three stages of sleep: initial, when a person feels tired, the middle stage, or "monkey's sleep", when a person sees dreams and the stage of deep sleep.

It is curious that in Book 4, karma is said to be only one of the seven causes for death, while six others lead to premature death. Here we see that early Buddhism was not fatalistic. In passages $58-60$, it is said that liberation is complete satisfaction, and it is completely free from all dissatisfaction. It is inexpressible, immeasurably formless, like the amount of water in the ocean or the number of its inhabitants, pure and free from pollution. It does not refer to the past, present or future, it is neither produced nor non-produced, it is not located in any place. Milinda asks if there is a place where liberation can be realized. Nāgasena replies that this place is virtue.

In the fifth book the question is posed: what is the evidence that the Buddha existed at all in reality, and the answer is given that the evidence of it is in his teachings, his prescriptions and meditative stages that belong to intersubjective experience.

The sixth book claims that laypeople also attain liberation, but taking monastic vows brings 46 good qualities. Moreover, for laypeople the attainment of liberation is impossible without having taken vows in one of their past lives.

Book Seven contains 67 different analogies for the good qualities in a monk, which are required to attain liberation, and are compared, in particular, to various animals. So, for example, the fact that a monk does not stay laying down for long is called "quality of the donkey"; "quality of the rooster" is that a monk goes to bed early and gets up early, and so on.

The seventh book ends with Milinda being completely satisfied with all Nāgasena's answers, adopting the Buddhist faith, handing over the kingdom to his son, and attaining the state of a perfect being. 
We can point out that Siderits [1] claiming himself to be a reductionist and, in fact, constantly trying to support reductionism by numerous arguments, basically is not a reductionist at all. De facto, he is an emergentist. This is very clearly shown by the following quote from his book. "The ability of a system to form and use selfrepresentations will clearly facilitate that system's self-scrutiny, self-control and self-revision capacities, and first-person psychological states are states that employ system self-representations. Causal connections among such states represent the exercise of these capacities. The normative dimension of these connections simply reflects the fact that such connections tend to promote overall maximization of welfare" [1. P. 51]. The quote makes it obvious that Siderits is actually a follower of systems theory and adheres to the view that such a complicated system as a person, being a compound causal sequence of states and processes, emerges or manifests itself in such qualities as self-representation or self-perception, which, in turn, directly affect the well-being of the system itself.

\section{"Milindapañha" on chariot $^{3}$}

1 .

And then King Milinda approached the venerable Nāgasena, and having approached the venerable Nāgasena, greeted him amicably, and having politely greeted him, sat down at a distance ${ }^{4}$. Then the venerable Nāgasena greeted him politely, which pleased the heart of King Milinda.

Then King Milinda said to the venerable Nāgasena:

- What is sir's name, how sir is called?

- My name is Nāgasena, o great king, the disciples address to me as

"Nāgasena", but it's the father and mother who give the name Nāgasena, or Sūrasena, or Vīrasena, or Sīhasena, but, o great king, this is only a designation (sankhā), a name (samaññā), a concept (paññatti), a conventional term (vohāra), only a name (nāma), this is Nāgasena, here no person (puggala) is perceived $^{5}$ (na upalabbhati).

Here, Nāgasena cites the famous "argument of imperceptibility"6, repeated later by Vasubandhu in his "Abhidharmakośabhāșya" (hereinafter AKB, chapter 9, "Pudglaviniścaya"). The argument of imperceptibility that has existed since the Pali

\footnotetext{
${ }^{3}$ Translated from the Pāli text [2] by Lev Titlin.

${ }^{4}$ In A. Paribok's translation [6]: "beside".

${ }^{5}$ T.W. Rhys Davids [3] translates as "no permanent individuality (no soul) involved in the matter" and in the notes explains: "it amounts to saying that there is no permanent subject underlying the temporary phenomena visible in a man's individuality".

${ }^{6}$ A. Paribok in his works, in particular, in the Introduction to the Russian translation of "Milindapañha", offers what can be called a "semiotic interpretation" of the issue. Thus, he argues that the discussion implies that " 'chariot' is a word used in connection with an object consisting of wheels, a pole, a basket and other parts, but from the word itself it is impossible to conclude what kind of object it is and what it is composed of", and 'Nāgasena' is "a mere word, used in connection with an individual composed of physical and mental elements" [6. P. 51]. We adhere to the ontological and epistemological interpretation, which is confirmed by such texts as "Kathavatthu", "Vajirā Sutta" and "Pudgalaviniścaya" of Vasubandhu (see below).
} 
Canon period boils down to the following: The "self" (ātman) is perceived neither by the ordinary senses, nor during a special meditation, from which it is concluded that it does not exist. This argument was also used in the debate with non-Buddhist philosophers, who also referred to the experience of self, but in their case, it was the experience of the Highest Ātman (in altered states of consciousness during moments of trance). The argument of imperceptibility can be compared to the argument of D. Hume ${ }^{7}$ against the existence of the "self" in his dispute with the rationalists ${ }^{8}$.

For Buddhism, the existing world is exhausted by the world of experience (that is, the totality of all the experienced objects), in other words, dharmas, or phenomena that have the status of ultimate reality. Vasubandhu recognizes two main epistemological tools (pramāna), with which in principle ātman could be known: direct perception (pratyakșa) and logical conclusion from effect to cause (anumāna).

According to Buddhism, direct perception is possible for seven of the twelve groups of dharmas (āyatanas) identified when considering the process of cognition. Only these seven āyatanas can be "objects" of cognition. These include: 1) visible - rūpa-āyatana, audible — sabda-āyatana, smell — gandha-āyatana, taste - rasa-āyatana, tangible — spraștavya-āyatana, objects of manas — dharmaāyatana and manas itself (see AKB 923).

Therefore, a logical conclusion from effect to cause is only required for the five remaining āyatanas - five sensual abilities, the need for which is proved by the fact that there is no sensory perception if they are not functioning (AKB 923924). Due to direct comprehension or logical conclusion, Vasubandhu believes, we are not able to perceive anything other than these twelve groups of dharmas (āyatanas). Since the ātman is not comprehended by any of the two epistemological tools, it cannot be attributed to the dharmas, or truly existent elements of reality. However, Vasubandhu negates the attman, or the "self, " not completely, but only as a reality (dravya), he considers it as a "name", a concept used in everyday human practice to denote a finite reality that is a constantly changing sequence of dharmas ${ }^{9}$.

In the 9th chapter of AKB Vasubandhu modifies and significantly strengthens the argument of imperceptibility of the àtman, turning it into a gnoseological argument. Vasubandhu's argument can be summarized as follows:

(1) There are only dharmas (realities, or elements of the reality).

(2) All dharmas are conceivable in experience.

(3) Comprehension is possible either a) due to direct perception (pratyakșa), or b) by means of a logical conclusion (anumāna).

(4) The âtman is comprehended neither by a) direct perception (since the perception of the âtman as a reality is not the object of actual experience), nor

\footnotetext{
${ }^{7}$ A. Gopnik makes an interesting assumption that D. Hume could at least have been familiar with Buddhist ideas through Jesuit missionaries in China [12].

${ }^{8}$ For details on this see [13].

${ }^{9}$ For details on this see [11].
} 
b) using a logical conclusion from effect to cause. Vasubandhu anticipates the principle of 'Occam's razor': he shows that introducing a new entity called àtman does not explain new facts of experience and does not add explanatory power to a theoretical system, and excluding the âtman from the system does not lead to disappearance of the necessary consequences (i.e., the facts of perception and cognition), which speaks of its logic redundancy. Not only Vasubandhu negates the àtman but declares that this "name" is not used to designate any other denotation, except for the set of psychophysical constituents of a person (skandhas) available in experience.

(5) It follows from this that the âtman is not a separate dharma (a reality).

(6) Consequently, the âtman does not exist as a finite reality, and can only be considered as a conventional reality (prajñāptisat).

The argument of imperceptibility is also present in the later text "Kathāvatthu" $\left(2^{\text {nd }}-3^{\text {rd }}\right.$ century AD), or "The Subjects of Discussion", part of the Abhidhamma-pitaka of the Pali Canon, which, among other things, includes a discussion between the "orthodox" Buddhists and the Pudgalavādins on the pudgala $^{10}$, or the "self", which has the synonyms atman (atta)), being (satta), life principle (jīva).

In this text, the Pudglavādins claim that the ātman, or pudgala, is "perceived" (upalabbhati) as "absolutely real" (saccikatțha-paramatthenā). What did the Pudgalavādins understand by this? The Pali verb upalabbhati ("to grasp, to acquire, to receive, to discover, to perceive, to know") has a complex meaning in which the epistemological connotations are intertwined with the ontological ones. As M. Kapstein [15. P. 79-81] points out, "upalabbhati" can be translated not only as "is found, is perceived," but also as "is present". In this regard, this verb is similar to the English "to be found", for example, in the sentence "No elephants are found in Russia" (literally, "In Russia, elephants are not discovered"). It is difficult to say in which of the meanings - ontological or epistemological - this verb is used in this early text on the edge of philosophy and pre-philosophy, but it can be said with certainty that in early texts the etymologically primary meaning of "seizure, perception" dominates, which is also confirmed by the text of the pre-Buddhist Chāndogya Upanișad, in which the verb "upalabh" - the Sanskrit analogue for the Pāli "upalabbhati" — found in the phrase "without knowing the Ātman, without approaching [its] knowledge" ("anupalabhyātmānam ananuvidya...") is clearly devoid of any ontological burden, and having a distinct epistemological meaning (this verb in the meaning of the knowledge of the Ätman is also found in the later Katha Upanișad). We can assume that in the passage in question we are talking about the perception, cognition of pudgala, which is confirmed by understanding pudgala as conventionally "conceivable" or "perceivable" on the basis of skandhas (āśraya-prajñapta-pudgala). However, in the passage of Kathāvatthu [I.1.1.3], the Pudgalavādins unequivocally deny that the pudgala is absolutely real (saccikațtho paramattho), which does not exclude the possibilities of ontological interpretation of the verb "upalabbhati".

\footnotetext{
${ }^{10}$ To consider this discussion we used the edition [14].
} 
The entire reasoning can be represented as follows. The Pudgalavādins claim that:

(1) Pudgala exist in a sense.

(2) Pudgala is perceived as absolutely really existing.

However, when asked by the Theravādins if they consider pudgala to be absolutely real (in fact, they ask whether pudgala is one of the dharmas), the Pudgalavādins respond negatively. Indeed, a positive answer to this question and the introduction of pudgala - which the Buddha did not recognize (but did not deny either) - as the 76th dharma, would be a gross violation of the tradition, which would be regarded not even as a "heresy", a false view, but as a negation of the anātmavāda, the foundation of the Buddhist teaching in general, leading to automatic exclusion of the Pudgalavādins from the group of the Buddhists. But they could not agree with this ${ }^{11}$.

And then King Milinda said this:

- Listen to me, gentlemen 500 Yavanas $^{12}$ and 80 thousand monks, this Nāgasena said thus: "The person is not perceived here, indeed". Is this right, is it possible to agree with this?

And then King Milinda said to the venerable Nāgasena:

- If indeed, sir Nāgasena, the person is not perceived, who in this case gives you [monks] clothing, food alms, bed and seat, support for sick, medicines, everything necessary, who enjoys it, who observes morality (sīla), who cultivates (bhāvanā) one's mind, who experiences the fruits of the Path and nibbāna, who commits murder, who commits theft, who lives in lust, who says untruth, who drinks heady beverages, who commits five immediately retributed deeds ${ }^{13}$ ? In this case there is neither good nor bad, neither a doer, nor a creator of good and bad deeds, neither there is any fruit of good and bad deeds, nor retribution for them. If that is so, sir Nāgasena, then if someone kills you, he does not commit an unrighteous deed, in this case you have neither a teacher nor a mentor, and there is no initiation [into the monks].

Here, King Milinda, while still misunderstanding Nāgasena in the key of annihilationism (reductionism), tries to argue him that if the self did not really exist, then there would be no subject of activity, there would not be anyone who enjoys the fruits of karma, of the Path and nirvāna, who does bad and good deeds, there would be no criminals, disciples and teachers, since their psycho-physiological components that are relevant for one moment, for example, when a person commits a crime, would be different from psycho-physiological components of another moment of time. Therefore, no one is punished, and no one becomes a teacher from a disciple.

\footnotetext{
${ }^{11}$ For details on this see [16].

${ }^{12}$ Yavanas (Skt. yavana, pali yonaka) is the name of the Greeks and the Hellenized peoples in the territory of India.

13 The five most heinous offenses that cause a direct postmortal retribution in hell (that is, a person takes rebirth in hell without being reborn in the other worlds) are parricide, matricide, killing an arhat (a man completely freed from defilements), spilling the blood of a Buddha, creating schism in the Buddist community (sangha-bheda).
} 
As you say: "O great king, my disciples call me Nāgasena, who," what is this Nāgasena? Perhaps, sir, is this Nāgasena's hair?

- It is not so, o great king.

- Maybe this is the hair on the body?

- It is not so, o great king.

- Nails, etc., teeth, skin, flesh, muscles, bones, bone marrow, kidneys, heart, liver, pleura, spleen, lungs, mesentery, intestines, stomach, excrements, bile, mucus, pus, blood, sweat, fat, tears, skin fat, saliva, snivel, synovial fluid, urine, the brain in the head is Nāgasena?

- It is not so, o great king.

Perhaps Nāgasena is [the group of material] sensuality ${ }^{14}$ (rūpa)?

- It is not so, o great king.

- Maybe Nāgasena is [the group] of sensations (vedanā)?

- It is not so, o great king.

- Maybe Nāgasena is the notions (saññā)?

- It is not so, o great king.

- Maybe Nāgasena is [the group] of karmic factors (sanikhāra)?

- It's not so, o great king.

- Maybe Nāgasena is [the group] of perceptions (viññāna $)^{15}$ ?

- It is not so, o great king.

- But then perhaps Nāgasena is all these together, [the group of material] sensuality, [the group] of sensations, the notions, [the group of] karmic factors, [the group] of perceptions?

- It is not so, o great king.

- Perhaps Nāgasena is something besides [the group of material] sensuality, [the group of] sensations, the notions, [the group of] karmic factors, [the group of] perceptions?

- It is not so, o great king.

- Sir, I am asking, I am asking about this Nāgasena, but I do not see him. Maybe Nāgasena is just a sound, o sir? But who is Nāgasena here indeed, you lie, sir, you say untruth, there is no Nāgasena here.

Milinda comes to annihilationism (in Siderits' interpretation), a direct denial of the existence of the self. In fact, this is nothing else but reductionism, the reduction of the individual to its components: the body, sensuality, sensations, concepts, karmic factors, consciousness. And it is with this - i.e., with reductionism - that Buddhism in the person of Nāgasena polemizes.

And then the venerable Nāgasena addressed Milinda the king like this:

- You, o great king, you are delicate, a very delicate kșatriya, walking on hot scorching land, on sand at midday time, your legs will be injured by sharp stones and hot gravel, and when the body becomes sick, the mind will come

${ }^{14}$ In our translation of the rūpa as sensuality, we proceed mainly from the translation tradition proposed by the outstanding Russian orientalist O.O. Rosenberg. See [17], chapter X. Sensual ("rūpa"). Rosenberg, in turn, proceeds from an understanding of "sensuality" by I. Kant, although in no way does he identify them.

${ }^{15}$ The five constituents (khandha) of a personality in Buddhism are being enumerated. 
to disturbance, there arises a bodily perception (kāyā-viñnāna), accompanied by pain. Did you come on foot or did you come [by vehicle]?

- I do not walk on foot; I came in a chariot.

- If you really came in a chariot, then tell me, what is a chariot? Is chariot the pole, o great king?

- No, sir.

- Is chariot the axle?

- No, sir.

- Is chariot the wheels?

- No, sir.

- Is chariot the basket?

- No, sir.

- Is chariot the flag ${ }^{16}$ ?

- No, sir.

- Is chariot the yoke?

- No, sir.

- Is chariot the spokes?

- No, sir.

- Is chariot the goad?

- No, sir.

- And perhaps, o great king, the pole, the axle, the wheels, the basket, the flag, the yoke, the spokes, the goad - all together are the chariot?

- No, sir.

- O great king, I am asking and asking about this chariot, but I cannot see it as the chariot is just a sound, o great king. But what is here the chariot? Lies you say, o great king, untruth, there is no chariot here, you, o great king, is the first king in Jambudvippa ${ }^{17}$, but why are you telling lies? Listen to me, gentlemen 500 Yavanas and 80 thousand monks, this King Milinda said thus: "I came in a chariot." If indeed you, o great king, came in a chariot, tell me what a chariot is! And he, while speaking, can achieve nothing. Is this right, is it possible to agree with this?

Here Nāgasena is entering into a kind of "word play" with King Milinda: he is trying to demonstrate the absurdity of reductionism. Just like before Milinda denied the existence of a person "Nāgasena", now Nāgasena himself denies the existence of the chariot, even though the king obviously cannot doubt its existence: he himself arrived on a chariot.

When this was said, 500 Yavanas approved the venerable Nāgasena and thus told King Milinda: "Now, o great king, if you can, please answer!"

And then King Milinda said to the venerable Nāgasena:

"I do not lie, sir Nāgasena, on the basis of (paticca) the pole and on the basis of the axle and on the basis of the wheels, and on the basis of the basket, and on the basis of the flag, and on the basis of the yoke, and on the basis of the

\footnotetext{
${ }^{16}$ Paribok translates as "handrails." In Rhys Davids' translation the word is omitted.

${ }^{17}$ Jambudipa (Skt. Jambudvipa) is one of the four continents in Buddhist cosmology, the abode of people.
} 
spokes, and on the basis of the goad, designation, concept, common designation, name, arises (pavattati ${ }^{18}$ ).

- Yes, o great king, well you know the chariot! Also, o great king, speaking of me, on the basis of the hair, and on the basis of the hair on the body, and so on, and on the basis of the brain and on the basis of [the group of material] sensuality, and on the basis of the notions, and on and on the basis of [the group of] karmic factors, and on the basis of [the group of] perceptions, there arises "Nāgasena" — designation, name, concept, common designation, only a name, but in the supreme sense (paramatthato), the person is not perceived here.

So, it was said by the nun Vajirā, in the face of Bhagavat, o great king:

Just as [on the basis of] members gathered together (sambhārā) ${ }^{19}$ there is the sound "chariot"

So, in the presence of khandhas there is a conditionally existing (sammuti) being (satta).

The same "argument of imperceptibility" was also proposed in the "Vajirā Sutta" (Samyutta Nikāya 5.10). In the Vajirā Sutta, historically later than the Buddha's sermons, Māra (incarnation of the affects) appears before the nun Vajirā and tries to lure her away from the true path, rousing in her the idea of a substantial "being" (Pāli: satta, in this case is a synonym for ātman):

\section{Māra:}

Who created this "creature" (satta)?

Where is the creator of the "being", where did the "being" come from, where will it disappear?

Vajirā:

Why do you believe in the "being", o Māra? You have now fallen into the [false] view!

It is just a heap of skandhas, the "being" is not perceived here (na upalabbhati).

Like the word "chariot" there is [only] a collection of members.

Truly in regard to the flow of skandhas (khandesu santesu)

"Being" is simply a common name (sammuti).

Only dissatisfaction (dukkha) arises,

And there is only dissatisfaction.

Nothing but dissatisfaction arises,

And nothing but dissatisfaction ceases to exist.

- It's wonderful, sir Nāgasena, amazing, sir Nāgasena, brilliant answers were given, if the Buddha were alive, he would approve of you, well, well, Nāgasena, brilliant answers were given!"

\footnotetext{
${ }^{18}$ The verb pavattati can also be translated as "exists".

19 The term sambhārā in "Milindapañha" means not a simple assembly, an aggregate, but preparation; sambhāraseda "bringing on by artificial means" [18. P. 694]. This is also indicated by the term anga - a member. That is, the chariot and the person here are understood as a functional whole.
} 
How many years have you [been an elder] ${ }^{20}$, sir Nāgasena?

- I am - seven years ${ }^{21}$, o great king.

- What is "seven", are you "seven" or this is the number "seven"?

And in the meantime, from King Milinda, adorned with all the jewels, dressed in ornaments, a shadow fell on the ground, and in a vessel with water his reflection could be seen.

And then the venerable Nāgasena thus addressed King Milinda:

- There is a shadow from thee, o king, and a reflection is seen in a vessel of water, but are you, o great king, a king, or the reflection of the king is the king?"

- I am, sir Nāgasena, the king, and not this reflection of the king is the king, on the basis (nissāya) of me the shadow and reflection arise.

- So, o great king, the number of years is "seven ", but I am not "seven", but on the basis of me "seven" arises, just like the shadow, o great king.

— It's wonderful, sir Nāgasena, amazing, sir Nāgasena, brilliant answers were given."

It should be noted that it is only when the doctrine of the emergence "on the basis of" was set forth that King Milinda begins to praise Nāgasena. That is, the teaching that there is no person at all, as well as no chariot, did not suit both opponents. As, however, they were not satisfied with the statement that they exist (in the ultimate sense). The statement that the self exists is true only at the level of relative truth (Sk. samvrittisat), the statement that the self and chariot do not exist at all is certainly false, both at the level of relative truth and at the level of absolute truth (Sk. paramārthasat). This is annihilationism (reductionism). At the level of absolute truth, it is true that the self and the chariot are nothing more than conventional names, only names for the parts "on the basis" of which they arise. But at the level of relative truth, the chariot and the person certainly exist, this cannot be denied, and they exist as derivatives, or emergent properties of such complex systems as "human" or "chariot", which are not reduceable to a mere assembly of parts.

2. And so, Anantakāya, walking next to Nāgasena, thus said to the venerable Nāgasena:

— Sir Nāgasena, when I say this: "Nāgasena", what is Nāgasena here?"

The venerable said:

- Where do you think here Nāgasena is?

— Sir, I think that "Nāgasena" is the inner wind, jīva ${ }^{22}$, which enters and exits.

- And if this wind comes out, and does not come in, or if it enters, it will not exit, will the person be alive?

\footnotetext{
${ }^{20}$ In the original - "kativasso si", literally just "how old are you". Paribok translates as "how many years have you [been in monkhood]". Nāgasena is repeatedly described in the text as āyasmā, "elder", "patriarch" or "venerable".

${ }^{21}$ In the original — "sattavasso 'haṃ», which can be understood as "I am seven," which was noticed by Milinda.

${ }^{22} \mathrm{Ji}$ va is an animating principle, the soul, understood as breathing, is often identified with the term attan (Skt. ātman).
} 
- No, sir.

- But if some people are playing on a bamboo pipe ${ }^{23}$, when they are blowing a pipe, does the wind come back in?

- No, sir.

- And if some people are blowing into a horn, when they blow the horn, does the wind come back in?

- No, sir.

- Then why don't they die?

- Very well, sir, I do not have the strength to fight with such words against such a thrower of arrows. Explain to me the sense.

- It is not jīva, it is only breathing in and out, bodily activity (kāyasankhārāa), explained the venerable in accordance with the Abhidharma.

And then Anantakāya became a worldly follower of [Buddhism].

In this passage from "Milindapañha", Nāgasena tries to convince the king's minister, Anantakayya, that the wind - that is, the inhalation and exhalation - is not a jīva, i.e., a soul. He argues that the soul as such, i.e., the self, does not exist; there are only "bodily manifestations" such as inhalation and exhalation.

3. The question of the existence of the self was also widely discussed in Vasubandhu's Abhidharmakośa-bhāṣya ( $4^{\text {th }}$ century), namely in the $9^{\text {th }}$ chapter of the text entitled "Pudglaviniścaya". Among other things, it contains a passage close by its sense to "Milindapañha". It contains Nāgasena's dialogue with King Kalinga (the researchers point out that this is the distorted name of Milinda, or Menander).

And this knot was undone by our predecessors.

After all when King Kalinga ${ }^{24}$ came to the venerable Nāgasena and said:

If I ask sir, and wandering ascetics indeed are lovers to talk, if I ask, then you, perhaps, will answer.

He allowed, and the questioner asked: "Is this living being (jīva) a body, or one is the living being, and another is the body?"

"This is inexplicable (lit. it is indeterminate) " — so said the venerable.

For the "inexplicable" or "undefined" in the text stands the philosophical term avyākṛta (avyākata), which means a range of "irrelevant" or "uncertain" questions that the Buddha consciously refused to answer. The following questions belong to it: is the world finite or infinite, does the Tathagata exist after death, and, of course, the question - debated in the text - whether the atman exists. A positive or negative answer to such questions, according to the Buddha, would be respectively either extreme eternalism (sassata-vāda), or nihilism (uccheda-vāda). Both of these views from the point of view of Buddhism are unacceptable, as they enslave a person in samsāra. It is interesting to note that the range of issues belonging to the category avyākṛta is very similar, both structurally and actually, to the Kantian antinomies of pure reason [19].

\footnotetext{
${ }^{23}$ Paribok translates as a "shell". Rhys Davids as "trumpeters".

${ }^{24}$ Distorted transfer of the name Milinda (Greek Menander).
} 
[Kalinga] said:

"But, oh, sir, before you made a promise to make an explanation!

Why was it said otherwise: "this is inexplicable"?

The venerable said: "I would also ask a question to the great king, and kings indeed are lovers to talk, if I ask something, then you, perhaps, will answer."

He allowed, and the questioner asked: "Are the fruits of mango tree in your inner chambers sour or sweet?"

"There is no mango tree in my inner chambers," so said [the king].

"After all, before, o great king, you gave me a promise to make an explanation

— nothing else was said!

Why was it said otherwise: "There is no mango [tree]?"

He said: "How shall I explain the sourness or sweetness of the non-existent tree?"

That is right, o great king, and there is no living being, how can I explain its difference or non-difference from the body?" "Pudgalaviniścaya"25, AKB, $938-939$ [20].

Here Nāgasena makes a summary. As it is impossible to explain the sourness or sweetness of the fruits of a non-existent tree, it is impossible to explain the identity or non-identity of the self to the body. Yet here in the text of the 4th century, we see a substantial shift in the paradigm of understanding the self in the philosophy of Buddhism. If in an earlier passage from "Milindapañha" Nāgasena only asserted that a person exists exclusively at the level of relative truth, in a conventional sense, but its existence was nevertheless recognized, in the passage above Nāgasena comes to a direct denial of the self's existence, that is, to annihilationism (reductionism).

\section{Discussion and Results}

We can conclude that while early Buddhism (i.e., at least in the 1st century AD, "Milindapañha"), as far as the self is concerned, adhered rather to systems theory and emergentism (non-reductionism), by the 4th century (Vasubandhu "Abhidharmakośa") there is already a significant shift towards annihilationism (reductionism), and the subject (the self, I) is starting to be directly negated in scientific treatises. We can also make a fairly reasonable assumption that, although the passage from the "Abhidharmakośa" being examined may have originally belonged to a possibly earlier version of "Milindapañha", anyway, in the form we have it now, it differs significantly from the root text. Moreover, it explicitly conveys ideas that are contrary to the spirit and letter of "Milindapañha", but, conversely, clearly consonant with the thoughts of the philosopher Vasubandhu and, obviously, ascribed by the latter to this excerpt from "Milindapañha", which, we can assume, was substantially modified in order to give it a new sense, while the formal outline of the exposition of the root text was not changed.

${ }^{25}$ The whole "Pudgalaviniścaya" (9th chapter of "Abhidharmakośabhāṣya" was translated into Russian and investigated by Lev Titlin [21]. 


\section{References}

[1] Siderits M. Personal Identity and Buddhist Philosophy. Aldershot, England: Ashgate; 2003.

[2] Trenckner V, editor. The Milindapañho: Being Dialogues Between King Milinda and the Buddhist Sage Nāgasena. London: Williams and Norgate; 1880.

[3] Rhys Davids TW, translator. The Questions of King Milinda. Oxford: The Clarendon Press; 1890, 1894.

[4] Horner IB, translator. Milinda's Questions. London: Wisdom Publications; 19631964.

[5] Pesala B, translator. The Debate of King Milinda [Internet]. Penang: Inward Path; 2001 [cited 2021 Apr 27]. Available from: http://www.buddhanet.net/pdf_file/ milinda.pdf

[6] Paribok AV, translator. The Questions of Milinda (the Milindapañho). M.: Nauka; 1989. (In Russian).

[7] Nyanatiloka T, translator. Die Fragen des Milindo. Bd. 1. Leipzig; 1919. Bd. 2. Munchen-Neubiberg; 1924.

[8] Finot L, translator. Milinda-Pañha. Les questions de Milinda. Paris: Bossard; 1923.

[9] Nolot É, translator. Entretiens de Milinda et Nāgasena: Version intégrale. Paris: Gallimard; 1995.

[10] Potter KH, editor. Encyclopedia of Indian Philosophies. Vol. VII. Abhidharma Buddhism to 150 A.D. Delhi: Motilal Banarsidass; 2006.

[11] Titlin LI. The Polemics Between the Buddhists and the Vaisheshikas on the Self in "Pudgalavinishchaya" of Vasubandhu. RUDN Journal of Philosophy. 2019;23(1):46-55.

[12] Gopnik A. Could David Hume Have Known about Buddhism?: Charles François Dolu, the Royal College of La Flèche, and the Global Jesuit Intellectual Network. Hume Studies. 2009;35(1):5-28.

[13] Giles J. The no-Self Theory: Hume, Buddhism, and Personal Identity. Philosophy East and West. 1993;43(2):75-200.

[14] Taylor AC, editor. Kathāvatthu. In 2 Vols. London: Pali Text Society; 1984.

[15] Kapstein M. Reason's Traces: Identity and Interpretation in Indian and Tibetan Buddhist Thought. Boston: Wisdom Publications; 2001.

[16] Titlin LI. The Concept of Pugdala in the Buddhist School of Pudgalavāda: the Problem of Interpretation and the Evolution of the Conception. RUDN Journal of Philosophy. 2014;1:105-111.

[17] Rosenberg OO. Problems of Buddhist Philosophy. In: Rosenberg OO. Works on Buddhism. Moscow: Nauka; 1991.

[18] Rhys Davids TW, Stede W, editors. The Pali Text Society's Pali-English dictionary. London: Chipstead; 1921-1925.

[19] Kant I. Works in German and Russian. Critique of Pure Reason. Vol. 2. Part 1. Moscow: Nauka; 2006. (In Russian).

[20] Shastri SD, editor. Abhidharmakosa \& Bhasya of Acharya Vasubandhu with Sphutartha Commentary of Acharya Yasomitra. Part II. Varanasi: Bauddha Bharati; 1970.

[21] Titlin LI. Vasubandhu. Abhidharmakośa, Book 9 "Pudgalaviniścaya" With the Commentary "Sputārtha" of Yaśomitra. Translation from Sanskrit, Introduction, Investigation and Comments by Lev Titlin. Moscow: Buddadharma; 2021. (In Russian). 


\title{
About the author:
}

Titlin Lev I. - CSc in Philosophy, Senior Research Fellow, Oriental Philosophies Department, Institute of Philosophy, Russian Academy of Sciences, Moscow, Russia (e-mail: titlus@gmail.com).

\section{Дискуссия о субъекте в «Милиндапаньхе»: новый перевод и комментарии}

\author{
Л.И. Титлин \\ Институт философии РАН, \\ Российская Федераџия, 109240, Москва, ул. Гончарная, 12/1, \\ titlus@gmail.com
}

\begin{abstract}
Аннотация. Приводится новый перевод на английский язык отрывков из «Милиндапаньхи» о субъекте и авторские комментарии к ним. Перевод предваряется кратким изложением произведения (по книгам и главам) и сведениями о существующих переводах на европейские языки. Автор полемизирует с такими представителями современной философии, как Сидеритс и приходит к выводу, что на самом деле Сидеритс является, скорее, не редукционистом, а эмерджентистом, или сторонником теории систем, что подтверждается его апелляцией к переводимым отрывкам из «Милиндапаньхи», которые автор предлагает рассматривать в ключе теории систем и утверждает, что ранний буддизм, как он дан нам, в частности, в рассматриваемом тексте, скорее склоняется не редукционизму и простому отрицанию «я» или «субъекта», но к мягкому варианту теории эмерджентизма. Автор выражает свое несогласие с «семиотической трактовкой» вопроса А. Парибка и в качестве подтверждения своей онтологическо-гносеологической трактовки отсылает к таким текстам, как «Катхаваттху», «Ваджира-сутта» и «Пудгалавинишчая» Васубандху. В конце статьи делается вывод, что если ранний буддизм (то есть еще как минимум в I в. н.э., в «Милиндапаньхе») в отношении субъекта придерживался, скорее, теории систем и эмерджентизма (нередукционизма), то к IV в. (Васубандху «Абхидхармакоша») происходит уже существенный сдвиг в сторону аннигиляционизма (редукционизма) и субъект («я») начинает уже напрямую отрицаться в научных трактатах.
\end{abstract}

Ключевые слова: Милиндапаньха, субъект, я, атман, анатман, нередукционизм, теория систем, эмерджентизм

\section{История статьи:}

Статья поступила 05.01.2021

Статья принята к публикации 10.02.2021

Для цитирования: Titlin L.I. Discussion on the Self in "Milindapañha" on Chariot: New Translation and Comments // Вестник Российского университета дружбы народов. Серия: Философия. 2021. Т. 25. № 2. С. 260-275. DOI: 10.22363/2313-2302-2021-25-2-260-275

\section{Сведения об авторе:}

Титлин Лев Игоревич - кандидат философских наук, старший научный сотрудник, сектор восточных философий, Институт философии РАН, Москва, Россия (e-mail: titlus@gmail.com). 